\title{
MESDC2/SENP1 Fusion Gene
}

National Cancer Institute

\section{Source}

National Cancer Institute. MESDC2/SENP1 Fusion Gene. NCI Thesaurus. Code $C 99745$.

A fusion gene that results from a chromosomal translocation which fuses exon 1 of the MESDC2 gene with exon 3 of the SENP1 gene. This rearrangement is associated with infantile sacrococcygeal teratoma. 